\title{
Probabilistic Analysis on Levelized Unit Electricity Cost (LUEC) Calculation of Small Medium Reactor Nuclear Power Plant (SMR NPP) In Indonesia
}

\author{
Nuryanti, Suparman
}

Center for Nuclear Energy System - National Nuclear Energy Agency (BATAN), Jl. Kuningan Barat, Mampang Prapatan, Jakarta

\section{Abstract}

Corresponding Author: Nuryanti, Suparman, email: nuryanti@batan.go.id

Received: 29 July 2016 Accepted: 21 August 2016 Published: 21 September 2016

\section{Publishing services} provided by Knowledge E

(c) Nuryanti, Suparman. This article is distributed under the terms of the Creative Commons Attribution License, which permits unrestricted use and redistribution provided that the original author and source are credited.

Selection and Peer-review under the responsibility of the ICONETS Conference Committee.

\section{OPEN ACCESS}

SMR NPP is an alternative to overcome the dependency to diesel power plant especially in outside Java Bali system. Economic analysis is a crucial thing that should be done prior to any investment decision on the SMR NPP project and generally done by calculation of Levelized Unit Electricity Cost (LUEC). NPP projects, include SMR, are vulnerable to a number of uncertainty variables. The goal of this study was to perform economic analysis of SMR NPP project with capacity $2 \times 100$ MWe in Indonesia by incorporating an amount of uncertainty variables, namely the probabilistic approach. The research method is calculating LUEC with deterministic approach followed by the probabilistic approach. Probabilistic approach is done by simulating the effect of uncertainty variable on LUEC using Monte Carlo simulation technique. The results show that the deterministic approach with a discount rate of $10 \%$ obtained LUEC at 12.87 cents US\$/kWh. Whereas the probabilistic approach obtained LUEC of 13.10 plus minus 1.43 cents USD/kWh at a discount rate of $10 \%$ and amounted to 8.11 plus minus 0.88 cents USD/kWh at a discount rate of $5 \%$. calculation in deterministic approach was 12.87 cents USD/kWh. While LUEC as the results of uncertainty variables simulation on probabilistic approach were $13.10 \pm 1.43$ cents USD/ kWh on discount rate $10 \%$ and 8.11 \pm 0.88 cents USD/kWh on discount rate $5 \%$. Occurrence probability of LUEC is less than 13 cents USD/kWh (benchmark value) was about $100 \%$ on discount rate of $5 \%$ and $50 \%$ on discount rate of $10 \%$.

Keywords: Uncertainties, probabilistic analysis, LUEC, Monte Carlo technique, SMR NPP

\section{Introduction}

The main characteristics of the electricity system outside Java-Bali are: limited grid (isolated areas) and still dominated by diesel power plants. Currently there are 4,640 units existing power plant, approximately 4,368 units $(94.14 \%)$ were diesel with an installed capacity reached to $36.94 \%$ of the total capacity [1]. Fuel price fluctuation as well as fuel supply chain up to the diesel location become a problem that lead to the high cost of electricity power generation in this region. Small Medium Reactor (SMR) could be an alternative to overcome the dependency of isolated areas to oil-fired power plants, because this reactor type was focused on the limited grid region $[2,3]$. The category of SMR encompasses the 
designs below $700 \mathrm{MWe}$, but new design layout and concepts are made possible by smaller size (i.e., from 350 MWe downwards) [2, 4, 5]. SMRs competitiveness lies on the higher degree of innovation implemented in their designs, improvement of safety aspects, as well as the lower initial capital costs compared to the large ones (although the unit cost USD/kWe higher at SMR NPP) $[3,6]$.

Economic analysis of electricity generation projects, generally done by calculating Levelized Unit Electricity Cost (LUEC), was crucial to be done prior to any investment decision on the SMR NPP project [7]. NPP project (include SMRs) are vulnerable to a number of uncertainties. Therefore an approach which is able to accommodate the possibility of these uncertainties was needed, namely probabilistic analysis [8,9].

There are many studies related to probabilistic analysis on electricity generation project $[3,10,11,12,13]$. This study focused on the SMR with specificity of Indonesia condition (infrastructure obstacle, payroll standard referring to PT PLN (Persero), etc.) [14]. Therefore the purpose of this study was to analyze the economics of SMR project in Indonesia considering the possibility of uncertainties. Study was conducted on SMR NPP $2 \times 100$ MWe. In this study, LUEC calculation performed by the deterministic approach first and then followed by the probabilistic approach. Probabilistic approach was done by simulating the effect of uncertainty variables simultaneously to LUEC. The probabilistic analysis performed by the Monte Carlo simulation techniques. Monte Carlo simulation is preceded by the development of a deterministic model that maps set of input variables to a set of output variables with some equations.

\section{Methodology}

\section{Levelized Unit Electricity Cost (LUEC)}

LUEC is the constant unit cost (per $\mathrm{kWh}$ ) of a payment stream that has the same present value as the total cost of building and operating a generating plant over its life [7]. Mathematically, the calculation of NPP LUEC expressed by equation (1) [18]:

$$
\text { LUEC }=\frac{\sum_{\mathrm{t}}\left(\frac{\text { Investment }_{\mathrm{t}}+\mathrm{Uss}_{\mathrm{t}}+\text { Fue } \mathrm{I}_{\mathrm{t}}+\text { Decommisioning }}{(1+\mathrm{t})^{\mathrm{t}}}\right)}{\sum_{\mathrm{t}}\left(\frac{\text { Electricity }}{(1+\mathrm{r})^{\mathrm{t}}}\right)}
$$

With:

$\begin{array}{ll}\text { Electricity }_{\mathrm{t}} & \text { : electricity production on year " } \mathrm{t} \text { " } \\ \text { LUEC } & \text { : Levelized Unit Electricity Cost } \\ \text { Investment }_{\mathrm{t}} & \text { : investment cost on year " } \mathrm{t} \text { " } \\ \text { O\&M }_{\mathrm{t}} & \text { : Operation\& maintenance cost on year " } \mathrm{t} \text { " } \\ \text { Fuel }_{\mathrm{t}} & \text { : Nuclear fuel cost on year " } \mathrm{t} \text { " } \\ \text { Decommisioning }_{\mathrm{t}} \text { : Decommisioning cost on year " } \mathrm{t} \text { " }\end{array}$

Based on engineering economic principle, equation (1) shows that basically LUEC is the quotient between the sum of all cost component and the sum of electricity production which was discounted to present value [19].

\section{Monte Carlo Simulation}

Monte Carlo simulation is defined as a statistical sampling technique used to estimate the solutions of the quantitative problems [15]. Monte Carlo simulation is preceded by the development of a deterministic model that maps set of input variables to a set of output 
variables with some equations. Furthermore, the deterministic model evaluated repeatedly with random numbers as input [16]. Repetition (iteration) is performed many times to ensure the robustness of the results $[3,17]$. Because the evaluation was done repeatedly then there was an uncertainty propagationas the basic principle of Monte Carlo simulation [18]. Scheme of deterministic model and uncertainty propagation could be seen in Figure 1 and Figure 2.

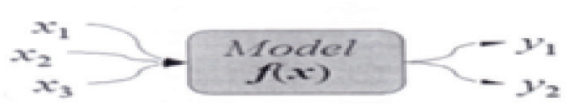

Note:

x 1, ..., xn : uncertainty variables as input

y1, ..., yn : output variables

Figure 1: Deterministic Model [16].
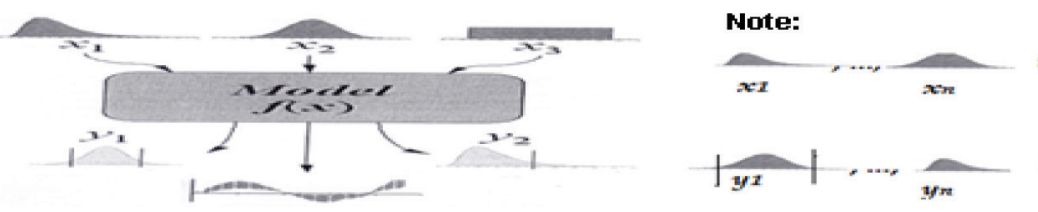

Distribution function of uncertainty wariables

Distribution function of output wariables

Figure 2: Uncertainty Propagation [16].

\section{Steps of Study}

The phases of study are as follows:

- Data gathering (technical and economic) that are required in the economic analysis

- Establish the necessary assumptions in the calculation

- Updating cost account data to the reference year (assumed in 2012)

- Calculating LUEC using deterministic models by using Mini G4ECONS, spreadsheet-based software from International Atomic Energy Agency (IAEA) [20].

- Distribution assignment of the uncertainty variables

- Simulating the uncertainty variables to the output (LUEC) by using @Risk [21].

- Analysis of the results and conclusion

\section{Data and Assumptions}

\section{Technical and Economics Parameters of Reference NPP}

Some techno-economic parameters of SMR NPP under study are shown at Table1.

TABLE 1: Techno-Economic Parameters of SMR NPP.

\begin{tabular}{|c|l|c|c|}
\hline No & \multicolumn{1}{|c|}{ Parameters } & Unit & Value \\
\hline $\mathbf{1}$ & Capacity & MW & $2 \times 100$ \\
\hline $\mathbf{2}$ & Capacity Factors & $\%$ & $93[22]$ \\
\hline 3 & Annually power production & MWh & $1,629,360,000$ \\
\hline 4 & Burn Up & MWd per metric tonne $U_{235}$ & 60,000 \\
\hline 5 & Discount rate & $\%$ & 10 \\
\hline 6 & Construction time & Year & 5 \\
\hline 7 & Project lifetime & Year & 40 \\
\hline 8 & Exchange rate & Rp per USD & $12,000,-[23]$ \\
\hline 9 & interest rate & $\%$ & $3.27[24]$ \\
\hline
\end{tabular}




\section{Structure of Electricity Generation Cost}

\section{a. Investment Cost}

The investment cost of nuclear power plants is often called as Overnight Cost that consisting of: EPC costs (Engineering Procurement Construction), development costs and other costs [15]. Table 2 states the SMR NPP overnight cost from several studies that have been converted to reference year with Power Capital Cost Index (PCCI) [25].

TABLE 2: Overnight Cost (OC) of SMR from Several Studies.

\begin{tabular}{|c|c|l|l|}
\hline No & Year & \multicolumn{1}{|c|}{ Reference } & OC (USD/kWe) \\
\hline 1 & 2010 & Electric Power Research Institute:'Typical SMR' [26] & $5,000-5,400$ \\
\hline 2 & 2011 & Nuclear Energy Agency: '4 x PWR-335' [26] & $4,900-5,300$ \\
\hline 3 & 2011 & Nuclear Energy Agency: '5 x PWR-125' [26] & $6,800-8,300$ \\
\hline 4 & 2010 & SMR Generic Estimated Cost [27] & $4,979-5,393$ \\
\hline 5 & 2009 & HTR (GIF-INPRO) [28] & $6,392-10,422$ \\
\hline
\end{tabular}

Overnight cost data in Table 2 is in the form of interval, then simulation techniques was performed to get the most probable value that can represent these values. From simulation, the most probable value is $6,288 \mathrm{USD} / \mathrm{kWe}$ (approximation to 6,300 USD/ kWe) or overnight cost is USD 1.26 billion. It was assumed that approximately $85 \%$ of this value would be EPC Cost, which is about USD 1.07 billion. Furthermore, taking into account the infrastructure obstacle related to the construction of nuclear power plants in Indonesia, there is an expensiveness factor whose value is approximately $15 \%$ of the EPC Cost. In addition, it is also considered a number of supplementary budgets (often termed as a contingency cost) that is approximately $20 \%$ of EPC Cost. Due to the infrastructure obstacle and the contingency cost, the total investment cost obtained for SMR $2 \times 100$ MWe is about USD $1,634,850,000$.

\section{b. Operation \& Maintenance (0\&M Cost)}

0 \& $M$ Cost is the cost required to run the routine operation of NPP, divided into two: fixed O\&M Cost and variable 0\&M Cost. Table 3 shows the structure of fixed $O$ \& $M$ Cost [14, 22]. While variable 0 \& $M$ costs was assumed approximately to 0.6030 USD/ MWh [29].

TABLE 3: Fixed O\&M Cost SMR NPP.

\begin{tabular}{|c|l|c|}
\hline No & \multicolumn{1}{|c|}{ Details } & Value (USD) \\
\hline 1 & Personnel Cost & $2,074,517$ \\
\hline 2 & $\begin{array}{l}\text { Maintenance Cost (include decommissioning } \\
\text { cost) }\end{array}$ & $15,804,792$ \\
\hline 3 & Property Tax & 10,553 \\
\hline 4 & Insurance Cost & 488,808 \\
\hline
\end{tabular}

\section{c. Nuclear Fuel Cost}

Table 4 shows the data of components of nuclear fuel cost. These costs are escalated to the first year of operation with escalation rate of 0,5\% (assumed to begin construction in 2019) [3]. 
TABLE 4: Details components of Nuclear Fuel Cost (USD) [30].

\begin{tabular}{|l|c|c|}
\hline \multicolumn{1}{|c|}{ Details of components } & Price in 2012 & Total Fuel Cost \\
\hline Price of $\mathrm{U}_{3} \mathrm{O}_{8}$ & 130 & 1,386 \\
\hline Conversion cost $\left(\mathrm{U}_{3} \mathrm{O}_{8}\right.$ to UF6) & 11 & 104 \\
\hline Enrichment & 120 & 1,207 \\
\hline Fabrication & 240 & 256 \\
\hline Total Fuel Cost $\left(\mathrm{USD} / \mathrm{kg} \mathrm{U}_{235}\right)$ & & 2,953 \\
\hline
\end{tabular}

\section{Distribution Assignment}

Several input variables that potentially cause uncertainty on LUEC, which are: investment cost, price of Natural Uranium $\left(\mathrm{U}_{3} \mathrm{O}_{8}\right)$, enrichment cost, fixed and variable O\&M cost, capacity factor and construction time [30]. Those variables were simulated simultaneously and furthermore their influence on LUEC could be seen.

There are three techniques in the distribution assignment. In case the historical data is available, the fitted distribution technique could be used. But, if the historical data is not available, generally researchers use literature approach and expert judgment. And if both of those techniques are not available, the final alternative used is assumption utilization [31]. Table 5 shows the result of uncertainty variables that affect the LUEC of SMR NPP.

TABle 5: Distribution Assignment of Uncertainty Variables.

\begin{tabular}{|c|c|c|c|}
\hline No & Uncertainty Variables & Type of Distribution & Note \\
\hline \multirow[b]{2}{*}{1} & \multirow[b]{2}{*}{ Investment Cost } & Triangular & \multirow[b]{2}{*}{$\begin{array}{l}\text { Fitted distribution of } \\
\text { historical data }\end{array}$} \\
\hline & & $\begin{array}{c}\text { minimum = 4,845; } \\
\text { most likely = 6,300; } \\
\text { maximum = 8,469 }\end{array}$ & \\
\hline \multirow{2}{*}{2} & \multirow{2}{*}{$\begin{array}{l}\text { Price of natural Uranium } \\
\left(\mathrm{U}_{3} \mathrm{O}_{8}\right)\end{array}$} & Pearson5 & \multirow{2}{*}{ Rothwell [30] } \\
\hline & & $\alpha=1.5420 ; \beta=28.437$ & \\
\hline \multirow{2}{*}{3} & \multirow{2}{*}{ Enrichment } & Normal & \multirow{2}{*}{ Rothwell [30] } \\
\hline & & $139.740 \pm 22.216$ & \\
\hline \multirow[b]{2}{*}{4} & \multirow[b]{2}{*}{ Fixed O\&M Cost } & Extvalue & \multirow{2}{*}{$\begin{array}{l}\text { Fitted distribution of } \\
\text { historical data }\end{array}$} \\
\hline & & $\begin{array}{l}\text { Mean }=90.1677 \\
\text { Std dev }=7.2447\end{array}$ & \\
\hline \multirow{2}{*}{5} & \multirow{2}{*}{ Variable O\&M Cost } & Logistic & \multirow{2}{*}{$\begin{array}{l}\text { Fitted distribution of } \\
\text { historical data }\end{array}$} \\
\hline & & $\alpha=0.620609, \beta=0.023733$ & \\
\hline 6 & Capacity Factor & $\begin{array}{c}\text { Triangular } \\
\text { minimum=0.88650; } \\
\text { most likely }=0.92593 ; \\
\text { maximum }=0.99191\end{array}$ & $\begin{array}{c}\text { Fitted distribution of } \\
\text { historical data }\end{array}$ \\
\hline
\end{tabular}

\section{Result and Discussion}

\section{The Result of LUEC Calculation on Deterministic Model}

In the calculation of LUEC using Mini G4ECONS models, the investment cost was disbursed during the construction period (investment disbursement). Furthermore, the investment cost was discounted at a certain interest rate to the Commercial Operation Date (COD). COD is 
the time at which the plant will be in commercial operation, so COD became the basis of the calculation. Considering the investment cost has been spent before the operation periods of the plant, then in LUEC calculation this investment cost should be discounted with a certain discount rate along lifetime of plants with a certain discount rate so that it become the annual value. The formula used for discounting the investment cost over the project lifetime is [7]:

$$
A I=I\left[\frac{r(1+r)^{n}}{(1+r)^{n}-1}\right]
$$

with:
Al: Annual Investment)
$\Gamma$ : discount rate
I : Total investment cost in year COD
$n$ : Plant lifetime

The notation of $\left[\frac{\mathrm{r}(1+\mathrm{r})^{\mathrm{n}}}{(1+\mathrm{r})^{\mathrm{n}}-1}\right]$ was called as fixed charge rate for capital levelization [7]. This annuity value is then divided by the total annual energy generated in order to obtain levelized investment costs that is expressed in USD/ kWh. Other constituent components of electricity generation cost (O\&M cost, nuclear fuel cost) were also converted into levelized O\&M Cost and levelized nuclear fuel cost (expressed in USD/kWh). Furthermore, the sum of all constituent components of electricity generation cost was called as levelized unit electricity cost (LUEC). The result of LUEC was presented in Table 6.

TABLE 6: The Result of LUEC Calculation on SMR NPP 2 x 100 MWe (cents USD/kWh).

\begin{tabular}{|c|c|c|}
\hline Note & Value & Percentage \\
\hline LUEC & 12.87 & \\
\hline Investment Cost & 11.15 & $86.66 \%$ \\
\hline O \& M Cost & 1.19 & $9.22 \%$ \\
\hline Fuel Cost & 0.53 & $4.10 \%$ \\
\hline Decommisioning Cost & 0.0015 & $0.01 \%$ \\
\hline
\end{tabular}

The result on Table 6 shows that LUEC of SMR NPP $2 \times 10$ MWe is 12.87 cents USD/kWh. Based on the percentage of each of the LUEC component, it could be seen that investment cost has the largest share in the LUEC structure (more than $80 \%$ ). It is consistent with the LUEC composition of NPP construction experience with technology from AREVA[32].

\section{The Result of Simulation on Uncertainty Variables to LUEC of SMR NPP}

Simulations were performed on two discount rate value (10\% and 5\%) with 1000 number of iterations. Selection of the discount rate were based on the consideration that $5 \%$ represents value for OECD (Organization for Economic Co-operation Development) countries and 10\% for non OECD [18]. Table 7 shows the simulation results of uncertainty variables to LUEC of SMR NPP.

TABLE 7: The Result of Simulations of Uncertainty Variables to LUEC (cents USD/kWh).

\begin{tabular}{|c|c|c|}
\hline Statistic & Discount rate 10\% & Discount rate 5\% \\
\hline Minimum & 10.06 & 6.25 \\
\hline Maximum & 26.14 & 18.61 \\
\hline Average & 13.10 & 8.11 \\
\hline Standard deviation & 1.43 & 0.88 \\
\hline
\end{tabular}


Based on Table 6 and 7, it could be seen that there was a difference on LUEC value between deterministic analysis and probabilistic analysis. In deterministic analysis (Table 6), LUEC value is in the form of single value (which is 12.87 centss USD/kWh). While in probabilistic analysis (Table 7), LUEC value is in the form of a distribution function of LUEC with a certain minimum, maximum and average value. But based on the statistical rules, LUEC value as simulation results (probabilistic analysis) can be assumed centered on the average value \pm standard deviation [33]. Therefore at discount rate of $10 \%$, LUEC value as simulation results would be at value of $13.10 \pm 1.43$ cents USD/ kWh, while at a discount rate of $5 \%$ would be at value of $8.11 \pm 0.88$ cents USD $/ \mathrm{kWh}$.It means that at discount rate of $10 \%$, LUEC value as simulation results will be centered on the value of 11.67 until 14.53 cents USD/kWh, while at discount rate of $5 \%$ will be on the value of 7.23 until 8.98 cents USD/ kWh. If the uncertainty variables aren't well monitored, then the LUEC value will be able to reach for the average plus standard deviation ( 14.53 cents USD/kWh at a discount rate of $10 \%$ and 8.98 cents USD/kWh at a discount rate of $5 \%$ ). The LUEC value which reaches for the average plus standard deviation is termed as risk adjusted LUEC [30]. In the opposite, if the uncertainty variables are monitored properly, then the LUEC value will be able to reach for the average minus standard deviation (11.67 cents USD/kWh at a discount rate of $10 \%$ and 7.23 cents USD/ $\mathrm{kWh}$ at a discount rate of $5 \%$ ). These results indicate that if the uncertainty variables are not monitored properly, it will very likely lead to cost overruns on generation costs. Therefore, policies that allow to monitor such uncertainty variables were needed.

Figures 3 and 4 shows the tornado diagram as simulation results of the uncertainty variables to LUEC at a discount rate of $5 \%$ and $10 \%$ respectively.

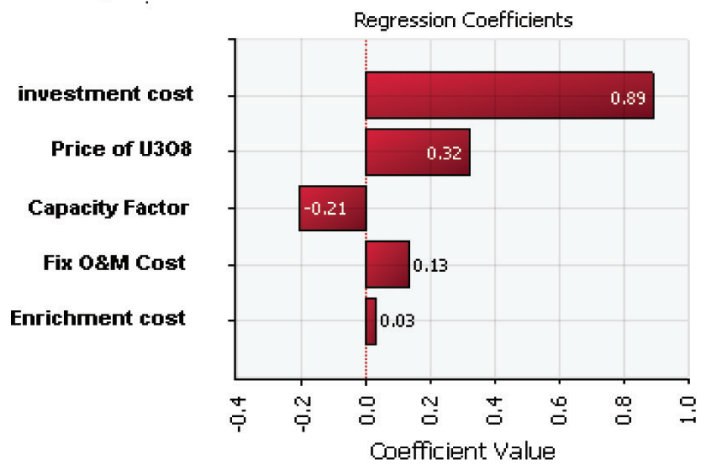

Figure 3: Tornado Diagram of SMR NPP LUEC PLTN SMR on Discount rate of 5\%.

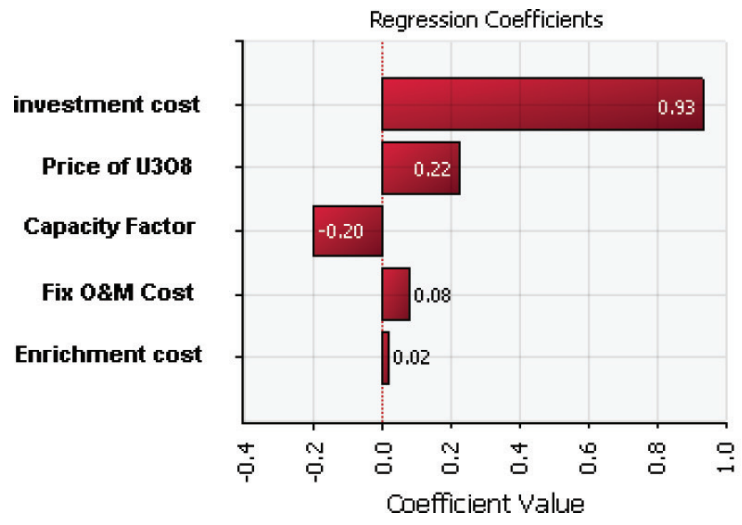

Figure 4: Tornado Diagram of SMR NPP LUEC on Discount rate of $10 \%$. 
Based on both figures, it can be seen that the investment cost has the largest coefficient value on both of the discount rate, this indicates that it is a very important variable to be monitored. Policies that allow to reduce the investment cost will contribute in lowering the LUEC value of SMR, for example by increasing the portion of national industrial participation in the project.

Figure 5 shows the cumulative distribution function (CDF) of simulation results of the uncertainty variables to SMR LUEC (in unit of mills USD/kWh) at discount rate of $10 \%$ and $5 \%$. The CDF in Figure 5 is used to determine the probability of occurrence that LUEC value is less than the benchmark value. The benchmark value is the LUEC value that will be assigned as the selling price of electricity from NPP company to utility company (PT PLN (Persero)) as agreed in the PPA (Power Purchase Agreement). SMR NPP is projected to be built in isolated area, as an alternative solution for the high cost of generation (generally diesel power plants were used) due to the high price of oil. Based on information from PLN, it is known that the price of electricity in isolated areas generally is about 12 cents USD/ kWh. Taking into account SMR is a relatively new technology for Indonesia, it is assumed that the benchmark value of LUEC for SMR is slightly more expensive at 13 cents USD/ kWh or 130 mills USD/kWh.

Based on Figure 5 shows that the occurrence probability of SMR LUEC is less than 13 cents USD/kWh for discount rate $5 \%$ is approximately $100 \%$, while at the discount rate of $10 \%$ the occurrence probability of LUEC is less than 13 cents USD/kWh is only about $50 \%$. These results indicate a need for a strong commitment from the government to provide a government guarantee on SMR NPP project, such as manifested by using low/ social discount rate. By decreasing in discount rate (from 10\% to $5 \%$ ), the occurrence probability of SMR LUEC is less than benchmark value will increase (from 50\% to 100\%) so it is expected that SMR NPP can compete with other power plants in outside Java-Bali System.

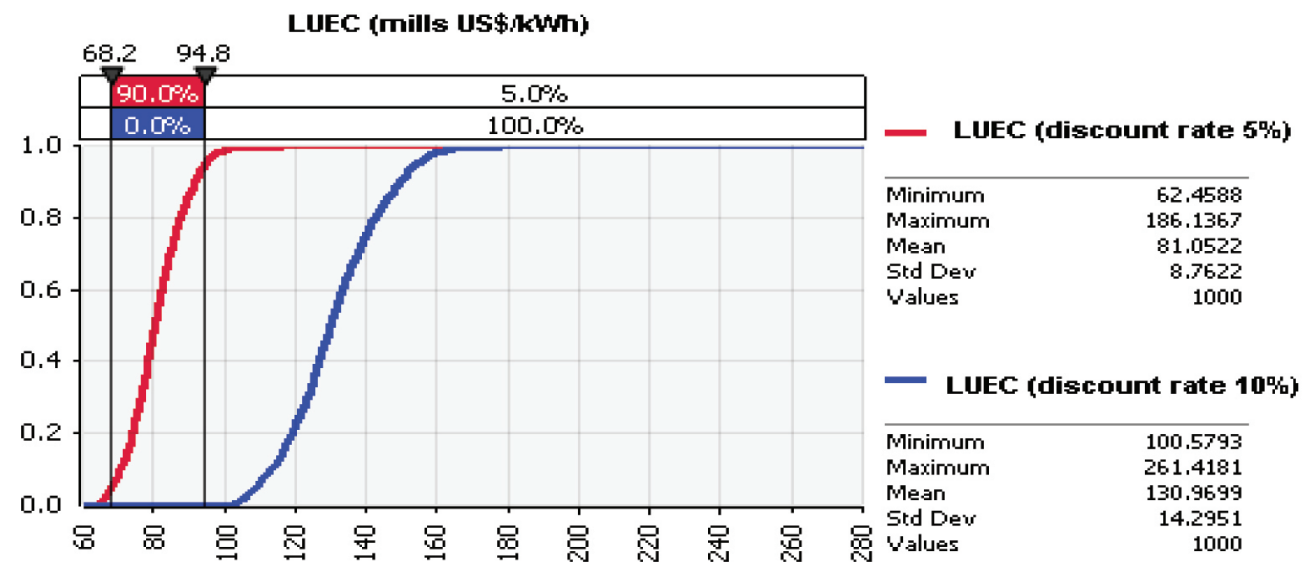

Figure 5: Cumulative Distribution Function (CDF) of SMR NPP LUEC as Result of Simulation on Uncertainty Variables.

\section{Conclusion}

Probabilistic analysis was proved to be able in accommodating the possibility of an amount of uncertainty variables occurrence in the SMR NPP project. The result of LUEC calculation with deterministic approach was amounted to 12.87 cents USD/ kWh. While the LUEC value as simulation results of uncertainty variables (probabilistic approach) was amounted to 13.10 \pm 1.43 cents USD/ kWh at a discount rate of $10 \%$ and of $8.11 \pm 0.88$ cents USD/kWh at a discount 
rate of $5 \%$. Variables that affect LUEC uncertainties should be monitored properly so that the occurrence of cost overruns on electricity generation cost could be avoided. The occurrence probability of LUEC is less than 13 cents USD/kWh (benchmark value) is approximately $100 \%$ at a discount rate of $5 \%$ and $50 \%$ at a discount rate of $10 \%$.

\section{Acknowledgment}

The research was granted by the IAEA in the form of Coordinated Research Project (CRP) entitled "Financing Model Considering Risk Analysis for Nuclear Power Plant In Indonesia" in 2014. An acknowledgement was submitted to Ir. Suroso Isnandar (PLN) and Dr. Sudi Ariyanto (BATAN) for intense discussion during the research accompany.

\section{References}

[1] PT PLN (Persero), "Statistik PLN 2013", Sekretariat Perusahaan PT PLN (Persero), Jakarta, ISSN No. 0852-8179, (Mei 2014)

[2] IEA/NEA, "Current Status, Technical Feasibility and Economics of Small Nuclear Reactors", OECD, Paris, (Juni 2011)

[3] LOCATELLI, G. dan MANCINI, M., "Small-medium Sized Nuclear, Coal and Gas power plant: A Probabilistic Analysis of Their Performances and Influence of $\mathrm{CO}_{2}$ Cost", Energy Policy, 38, pp. 6360-6374, (2010).

[4] PETROVIC, B., RICOTTI, M., MONTI, S., CAVLINA, N. dan NINOKATA, H.,"Pioneering Role of IRIS in the Resurgence of Small Modular Reactors", Nuclear Technology, Vol. 178, No. 2, Pp. 126-152, (2012).

[5] REYES, J. dan LORENZINI, P., "NuScale: A Modular, Scalable Approach to Commercial Nuclear Power", Nuclear News, (2010).

[6] BOARIN, S. dan RICOTTI, M., "Research Article: An Evaluation of SMR Economic Attractiveness", Hindawi Publishing Corporation, Science and Technology of Nuclear Installations, Volume 2014, Article ID 803698, (2014).

[7] BLACK \& VEATCH, "Levelized Cost of Energy Calculation, Methodology and Sensitivity", http://csep.efchina.org/Levelized Cost of Energy Calculation_BV_EN.pdf. Accessed on 18 February 2014.

[8] RODE, et al.,"Montecarlo Methods for Appraisal and Valuation: A Case Study of a Nuclear Power Plant", CEIC Working Paper 01-01, Carnegie Mellon Electricity Industry Centser, Carnegie Mellon University, Pittsburgh, (2001).

[9] FITRIANI, H. et al., "Kajian penerapan model NPV-at-risk sebagai alat untuk melakukan evaluasi investasi pada proyek infrastruktur jalan tol", Jurnal Infrastruktur dan Lingkungan Binaan Vol. II No. 1, Hal. 1-12 (Juni 2006).

[10] FERETIC, D., \& TOMSIC, Z.,"Probabilistic analysis of electrical energy cost comparing: Production costs for gas, coal and nuclear power plants", Energy Policy,33, pp. 5-13, (2005).

[11] Roques, A. et al., "Using probabilistic analysis to value power generation Investment under uncertainty", EPRG 065, Electricity Policy Research Group (EPRG), University of Cambridge, England, (2006).

[12] NURYANTI, "Studi Kelayakan Finansial Proyek PLTN di Indonesia dengan Memasukkan Unsur Ketidakpastian", Thesis, Fakultas Teknik Universitas Indonesia, (2012). 
[13] NURYANTI, dkk., "Analisis Probabilistik Pada Perhitungan Biaya Pembangkitan Listrik Teraras PLTN", Jurnal Pengembangan Energi Nuklir, Volume 14 No. 1 Hal. 23-33, Jakarta (2012).

[14] PUSLITBANG PT PLN (Persero) dan PPEN-BATAN, "Laporan Akhir: Studi Ekonomi, Pendanaan dan Struktur Owner dalam Rangka Rencana Persiapan Pembangunan PLTN Pertama di Indonesia", PLN, Jakarta (2006).

[15] HOLTON, Glyn A., Value-at-Risk: Theory and Practice, $2^{\text {nd }}$ ed, E-book at http://value-at-risk. net, Accessed on 4 February 2012

[16] SRIDADI, B.,"Pemodelan dan Simulasi Sistem: Teori, Aplikasi dan Contoh Program dalam Bahasa C", Penerbit Informatika, Jakarta, (2009).

[17] TJONG, W., F., "Aplikasi Statistik Ekstrim dan Simulasi Monte Carlo dalam Penentuan Beban Rencana pada Struktur dengan Umur Guna Tertentu", Dimensi Teknik Sipil, Vol. 3, No. 2, September 2001, Hal. 84-88 (2001), ISSN 1410-9530.

[18] IEA/NEA, "Projected Cost of Generating Electricity (2010 Edition)", OECD, Paris, (2010)

[19] BLANK \& TARQUIN, "Engineering Economy", 6th, Mc Graw Hill, Singapore, (2008)

[20] IAEA,"Mini G4 Econs Software", IAEA, Vienna, (2008)

[21] PALISADE CORPORATION,"Guide to using @Risk: Risk Analysis and Simulation Add-In for Microsoft Excel Version 5.5", (May 2009)

[22] PT PLN (Persero), PT LAPI ITB \& JAPC,"Feasibility Study for Bangka Nuclear Power Plant Project - Non Site aspect", (2013)

[23] BANK INDONESIA, "Foreign Exchange Rate in Year 2012", http://www.bi.go.id/ [Accessed on 01 June 2014]

[24] OECD, "Commercial Interest Reference Rate (CIRRs)",www.oecd.org/tad/xcred/cirrs.pdf. [Accessed on 01 June 2014]

[25] _ "Power Capital Cost Index (PCCl) North America", http://www.ihscera.com/ [Accesed on 05 Mei 2014]

[26] ABDULLA, A. \& AZEVEDO, I. L., "Developing a Range of Levelized Cost Estimates for Integral Light Water Small Modular Reactor", www.andrew.cmu.edu, [Accessed on Mei 2014]

[27] US DEPARTMENT OF ENERGY, "SMR Financing and Economics, The Nuclear Option: Is Small Scale Nuclear Energy an Option for Alaska?", December 2010

[28] ONO, K., "Generation IV International Forum Economics Assessment Methodology and Application", GIF-INPRO Interface Meeting, Vienna, March 1, 2013

[29] ROTHWELL, G., "The Economics of Future Nuclear Power: An Update of The Economic Future of Nuclear Power (2004), a Study Conducted at the University of Chicago", Stanford University, (2011)

[30] _ _The Economics of Nuclear Power,Updated August 2013", http://www.worldnuclear.org/info/inf02.html [Accessed on 15 Desember 2013]

[31] YE, S. \& TIONG, R.,"NPV at risk method in infrastructure project investment evaluation, Journal of Construction Engineering and Management, Vol. 126, No. 3 Pp. 227-233 (May/ June 2000), ISSN 0733-9634/00/0003-0227-0233.

[32] THOMAS, S.,"The economic of nuclear power: An update", Berlin: Heinrich-Böll-Stiftung, March 2010, http://www.psiru.org/ [Accessed on 03 Februari 2012]

[33] SUPRANTO, J., "Statistik: Teori dan Aplikasi, Jilid 1", Edisi 7, Penerbit Erlangga, Jakarta, (2009) 